\title{
Uwagi nad książka Józefa Koredczuka pt. Dziedziczenie nieruchomości w świetle orzecznictwa sądów apelacji lwowskiej w okresie międzywojennym, E-Wydawnictwo. Prawnicza i Ekonomiczna Biblioteka Gyfrowa. Wydziat Prawa, Administracji i Ekonomii Uniwersytetu Wrocławskiego, Wroctaw 2019, ss. 289; JSBN 978-83-66066-57-1 (druk) i JSBX 978-83-66066-58-8 (online)
}

\section{Abstract}

A Review of Józef Koredczuk's Book, Entitled The Jnberitance of Real Estate in Light of the Case-law of the Lviv Appellate Circuit Courts in the Second Polish Republic, The E-Wydawnictwo. Prawnicza i Ekonomiczna Biblioteka Cyfrowa. Wydział Prawa, Administracji i Ekonomii Uniwersytetu Wrocławskiego, Wrocław 2019, 289 p.; ISBN 978-83-66066-57-1 (druk) i ISBN 978-83-66066-58-8 (online)

The reviewed book by Dr. Jozef Koredczuk entitled The inheritance of real estate in light of the caselaw of the Lviv Appellate Circuit courts in the Second Polish Republic is a monograph. It is a pioneer elaboration in the history of Polish law. The theme of the book focuses on cases regulated primarily by the Austrian Civil Code (ABGB) of 1811. This Code was binding in the Polish territory of the so-called Galicia (today, the Malopolska region) for almost 135 years, from 1812 until the end of 1946. The author narrows his research down to the jurisdiction of the Lvi'v appellate courts between 1918 and 1939. The author does not go directly to court records, but to previously published judicial decisions and their justifications. The researcher's subject of interest is the inheritance of real estate, and thus leaving inheritance of chattels and rights behind.

Keywords: the Austrian Civil Code, ABGB, Austrian inheritance law, inheritance of real estate

Słowa kluczowe: austriacki kodeks cywilny, ABGB, austriackie prawo spadkowe, dziedziczenie nieruchomości 


\section{Wstęp}

1.1. Recenzowana książka autorstwa Józefa Koredczuka nosi tytuł Dziedziczenie nieruchomości w świetle orzecznictwa sadów apelacji lwowskiej w okresie międzywojennym i ma charakter poważnego opracowania monograficznego ${ }^{1}$. Tematyka tej książki koncentruje się wokół spraw regulowanych przede wszystkim ustawodawstwem austriackim Austriackiego Kodeksu Cywilnego (ABGB) z 1811 r., który obowiązywał na ziemiach polskich w Galicji (Małopolsce) przez prawie 135 lat, poczynając od 1812 r. aż do końca 1946 r. Niemniej tytuł książki wskazuje, że jej Autor dość precyzyjnie zdefiniował zakres swoich badań naukowych w wymiarze terytorialnym, czasowym, jak i przedmiotowym (merytorycznym). Z jednej strony słusznie zawęża zakres swoich badań - jak czyni to większość wprawnych badaczy, ale z drugiej strony jest to materia wystarczająca do poważnych badań i prezentowania dorobku naukowego. Koncentruje się przede wszystkim na okresie międzywojennym, tzn. na latach 1918-1939; terytorialnie zaś zawęża swoje badania tylko do właściwości sądów apelacji lwowskiej. Głównym obszarem Jego dywagacji naukowych są zagadnienia, które były przedmiotem orzecznictwa sądowego, a więc korzysta $\mathrm{z}$ owoców praktyki (akt sądowych) i prawa sądowego, gdzie głos doktryny - chociaż bardzo ważny i determinujące te badania - jest niejako w tle, a uwypukla się przede wszystkim praktykę stosowania prawa, zwyczaj i społeczne przyzwyczajenia. Autor nie sięga wprost do akt sądowych, ale do opublikowanych swego czasu drukiem orzeczeń sądowych i ich uzasadnień. Przedmiotem zainteresowań Badacza pozostaje dziedziczenie rzeczy nieruchomych, a zatem na uboczu pozostawia spadkobranie rzeczy ruchomych i praw. Wreszcie badania te są zawężone tylko do jednego ze sposobów przekazywania własności nieruchomości w drodze czynności mortis causa - czyli w zakresie tylko dziedziczenia, więc poza obszarem zainteresowań naukowych pozostawia obrót inter vivos.

Zatem zakres podjętych badań naukowych jest dość obszerny czasowo, terytorialnie i przedmiotowo. Stwierdzam, że w pełni nadaje się na tego typu opracowania o charakterze monograficznym. Omawiana w recenzowanej książce instytucja miała (i ma nadal) w Polsce niezwykle istotne znaczenie prawne, społeczne i gospodarcze. Pochwalić należy Autora książki, że w swoich rozważaniach trzyma się tematyki zakreślonej w jej tytule. Ponadto należy docenić intuicję naukową ukierunkowaną na tego typu, niszowe i poniekąd zapomniane, chociaż bardzo potrzebne, badania. Tym bardziej że stan badań $\mathrm{z}$ wykorzystaniem materiału źródłowego zawartego w aktach sądowych $\mathrm{w}$ zachodnioeuropejskiej nauce historycznoprawnej i socjologicznoprawnej jest już mocno zaawansowany i poniekąd wyprzedzający nasz stan badań o epokę, a może i dwie.

1.2. Józefa Koredczuka do podjęcia się tego tematu książki miało skłonić kilka powodów natury naukowej i praktycznej (orzeczniczej). Przede wszystkim to, że poaustriackie prawo spadkowe w okresie Polski międzywojennej, a przede wszystkim praktyka

\footnotetext{
${ }^{1}$ Niniejsza recenzja nawiązuje w swojej treści istotnie do mojej wcześniejszej recenzji wydawniczej przedmiotowej książki Józefa Koredczuka, którą sporządziłem na etapie procesu wydawniczego. Recenzję wydawniczą w formie pisemnej przedstawiłem władzom Uniwersytetu Wrocławskiego i uzyskałem Ich zgodę na opublikowanie drukiem niniejszego tekstu.
} 
jego stosowania, nie doczekały się jak dotychczas należytych opracowań naukowych. Chociaż, jak sam Autor przyznaje, w zakresie opracowań regulacji prawnych oraz doktryny stosowania prawa spadkowego „pierwsze kroki już poczyniono” (s. 15).

Drugim powodem naukowego zainteresowania Autora książki tą tematyką jest fakt, że zachodziła czasami szalona rozbieżność między normami ABGB u progu XX w. a „rzeczywistością ekonomiczną oraz społeczną” (s. 16). Wreszcie poaustriacki k.c. (ABGB) ma czasami zastosowanie w praktyce orzeczniczej współczesnej Polski, w szczególności przy dochodzeniu roszczeń odszkodowawczych naszych obywateli lub ich spadkobierców za mienia zabużańskie czy też dla mieszkańców przemyskiego, którzy chcą regulowania spraw spadkowych po swoich przodkach mieszkających we właściwości dawnego lwowskiego Sądu Apelacyjnego.

Przedstawione opracowanie jest $\mathrm{w}$ zasadzie pierwszym w polskiej literaturze przedmiotu, które poważnie uzupełnia lukę w stanie wiedzy z zakresu międzywojennego prawa spadkowego z terenów Galicji Wschodniej. Znajdziemy tu niezwykle istotne, naukowo ciekawe ustalenia, które oczywiście nie kończą badań w tym zakresie, ale w istotny sposób posuwają je naprzód. Zatem chwała Autorowi za tak cenny pomysł badawczy.

\section{Struktura pracy}

Omawiana książka liczy 289 stron. Opracowanie ma klasyczny układ, tj. składa się z 14-stronicowego wstępu (s. 13-26), 181-stronicowej części merytorycznej (s. 27-207) i 11-stronicowego zakończenia (s. 209-219). Na końcu książki Józef Koredczuk zamieścił aneks, a w nim wykaz sądów apelacji lwowskiej (s. 221-222), dalej wykaz aktów prawnych (s. 223-226), wykaz orzeczeń sądowych (s. 226-246), wykaz drukowanych źródeł prawa i zbiorów orzeczeń sądowych (s. 246-248), dalej zaś wykaz cytowanej literatury (s. 248-263) i wreszcie indeksy: indeks artykułowy (s. 265-270), indeks osobowy (s. 271-276) i na samym końcu indeks nazw geograficznych (miejscowych) (s. 277-280). Opracowanie zwieńczone jest krótkim streszczeniem w thumaczeniu na język angielski (s. 281-284) i niemiecki (s. 285-289). Kolejność wymienionych składowych oraz ich treść jest w pełni prawidłowa.

$\mathrm{Na}$ wstępie recenzowanej książki znalazły się takie elementy, jak spis treści (s. 9-10), wykaz skrótów (s. 11-12) oraz wstęp, w którym opisano: cel pracy, literaturę i źródła oraz układ pracy. Książka wzbogacona została o autorską tabelę obrazującą zmiany legislacyjne w ABGB w zakresie spadkobrania w 1914 i 1916 r. (s. 43).

Merytoryczna część książki składa się z pięciu rozdziałów o nierównej objętości. Treść poszczególnych rozdziałów jest zróżnicowana i w zasadzie zgodna $\mathrm{z}$ ich tytułami. Czasami dostrzec można sformułowania nazbyt ogólne i nieostre, a także sporo uproszczeń i skrótów myślowych. Zdarzają się też pominięcia, co może rodzić niedosyt u czytelnika, ale oznacza to, że poruszana przez Autora tematyka wymaga jeszcze dalszych badań i studiów, zarówno prawników, jak i historyków oraz specjalistów innych dziedzin.

W recenzowanej książce elementy statyczne przeplatają się z dynamicznymi w różnej konfiguracji, przy czym te ostatnie zdecydowanie przeważają. Moim zdaniem budowa 
pracy jest przemyślana, logiczna i w pełni koresponduje z budową typowych opracowań (monografii) historycznoprawnych pisanych w związku z ubieganiem się o tytuł naukowy lub stopień naukowy w zakresie historii prawa. Również co do struktury i budowy wstępu nie można mieć zastrzeżeń. Książka stanowi kompletne opracowanie tematyki określonej w jej tytule.

W zasadzie każdy ważniejszy wywód w części merytorycznej książk dokumentowany jest przypisem, których w całej pracy użyto konieczną, ale niezbyt dużą liczbę (565). Autor zastosował ciągłą numerację przypisów od początku do końca książki. W zasadzie zostały zachowane prawidłowe proporcje pomiędzy tekstem właściwym a przypisami, które zwykle nie przekraczają 1/3 objętości strony, ale w wielu przypadkach są obszerniejsze. W treści przypisów znajdziemy przede wszystkim wątki naukowe zaczerpnięte z literatury przedmiotu lub z orzeczeń sądów apelacji lwowskiej albo Sądu Najwyższego. W moim odczuciu są wątki, które rodzą niedosyt i ciekawość badawczą.

\section{Zastosowane metody badawcze}

Józef Koredczuk w swojej książce zastosował kilka znanych naukom historycznoprawnym metod badawczych. Chęć zbadania różnych instytucji prawnych i zjawisk historycznoprawnych im towarzyszących oraz stan i dostępność materiału źródłowego zdeterminowały dobór tych metod badawczych. Dominuje metoda dogmatyczna. Konieczność jej zastosowania wynikała $\mathrm{z}$ tego, że Autor monografii - kierując się treścią źródła prawa w obrębie prawa spadkowego, jakim był ABGB - dopasował niejako do książki treści z sentencji i uzasadnień wyroków sądowych. Zabieg ten był niezwykle pracochłonny i wymagał znacznego wysiłku intelektualnego. W recenzowanej książce znajdziemy także wiele treści opracowanych z wykorzystaniem metody historycznoprawnej. Była ona konieczna przy opisywaniu losów niektórych instytucji i zmian legislacyjnych austriackiego prawa spadkowego w latach 1914-1916, ale i wcześniej oraz później (zwłaszcza w II RP). Metoda ta jest wyjątkowo przydatna do ukazania etapów kształtowania się tych instytucji i wpływów na ostateczny kształt prawa spadkowego z ABGB.

W opracowaniu znajdziemy także zastosowanie statystycznej metody badawczej. Jej rezultaty są szczególnie widoczne przy wnioskach i opisywaniu kierunków ewolucji oraz zmian w obrębie zachowań spadkowych ówczesnych mieszkańców Polski południowo-wschodniej.

Stwierdzam, że dobór przez Autora książki metod badawczych jest prawidłowy i zasługuje na bardzo wysoką ocenę.

\section{Wykorzystanie źródeł i literatury}

Autor książki wykorzystał przede wszystkim publikowane drukiem orzeczenia sądów apelacji lwowskiej w zakresie prawa spadkowego ze szczególnym ukierunkowaniem na 
dziedziczenie nieruchomości, w tym gospodarstw rolnych w latach 1918-1939. Zestawił 57 źródeł prawa - aktów prawnych wykorzystanych w opracowaniu. Są tu źródła prawa austriackiego z XIX w., ale i z początków wieku XX. Ponadto jest tu garść aktów normatywnych rosyjskich (i radzieckich), ale i niemieckich. Znajdziemy tu również źródła prawa polskiego okresu międzywojennego o różnej hierarchii, od konstytucji marcowej z 1921 r. do rozporządzeń resortowych.

Wykaz orzeczeń sądowych - będących głównym źródłem badań naukowych - liczy aż 348 pozycji, które są ułożone chronologicznie - od najstarszego poczynając, a na najmłodszym kończąc, przy czym datą końcową jest rok 1939. Wśród nich znajduje się 11 orzeczeń wiedeńskiego Najwyższego Trybunału z przełomu XIX i XX w. oraz 331 orzeczeń polskich sądów, wśród których dominują wyroki Sądu Najwyższego w Warszawie oraz trzy orzeczenia Naczelnego Trybunału Administracyjnego (NTA), a także wyroki sądów powszechnych (cywilnych) z apelacji lwowskiej. Dominują oczywiście wyroki lwowskie, tzn. Sądu Krajowego, a później okręgowego i apelacyjnego, ale są też wyroki sądów powiatowych z apelacji lwowskiej. W mojej ocenie jest to materiał w pełni wystarczający do przedstawienia analizowanej instytucji. Jest wielką szkodą dla nauki, że w zdecydowanej większości spraw ten materiał archiwalny w postaci akt sądowych nie zachował się do naszych czasów.

Literatura przedmiotu jest dosyć obszerna (liczy 212 pozycji), wszystkie polskojęzyczne, brakuje obcych, przede wszystkim austriackich. Niemniej jest to zabieg Autora w pełni świadomy i chyba uzasadniony. Są to publikacje o różnej metryce wydania (niektóre z końca XIX w. - np. Ernesta Tilla i Fryderyka Zolla), dominują publikacje z okresu II RP, ale wykorzystano też parę z okresu Polski Ludowej, i wreszcie niektóre dość niedawne, z przełomu XX i XXI w. Znajdziemy tu przede wszystkim artykuły przeglądowe, analityczne i przyczynkowe, komentarze do kodeksów, monografie, zbiory orzeczeń sądowych, glosy, recenzje i inne typy publikacji naukowych. W tym wykazie jest aż sześć pozycji Józefa Koredczuka, pozostających w bezpośrednim związku z tytułem książki. Recenzowana książka jest zatem jakby zwieńczeniem pewnego etapu badań Autora w obrębie historii prawa spadkowego w Galicji wschodniej z czasów II RP.

\section{Wartość merytoryczna pracy}

5.1. Rozdział pierwszy zatytułowany "Zagadnienia związane z dziedziczeniem nieruchomości w byłym zaborze austriackim w okresie międzywojennym" ma charakter wybitnie statyczny. Omówiono tutaj organizację poaustriackiego wymiaru sprawiedliwości przejętą przez Polskę w 1918 r. i nasze polskie próby dostosowawcze z lat 1918-1919 i dalej jego poważną unifikację w $1928 \mathrm{r}$. Analizowane tu są szczegóły związane z przejęciem spraw z wiedeńskiego Najwyższego Trybunału przez warszawski Sąd Najwyższy i jego trzecią izbę „Małopolską" oraz zakres ich kompetencji, podobne jak administracyjnego NTA, a także obsadę personalną SN. Okazuje się, że sędziowie ci byli prawnikami fachowcami z bogatym stażem orzeczniczym w Wiedniu. Omówiono tutaj również zmiany w SN po 1933 r. oraz działalność izb notarialnych. Szerszej analizie poddano podstawy prawne dziedziczenia nieruchomości i tradycję oraz zwyczaje, a także spo- 
łeczną świadomość $\mathrm{w}$ tym zakresie. Cennym uzupełnieniem jest tabela 1 , gdzie naszkicowano różnice w nowelach ABGB okresu wojennego, tzn. Pierwszą z 1914 r. i Trzecią z 1916 r. Ważną sprawą było ograniczenie parantel przy dziedziczeniu ustawowym z sześciu do czterech oraz poszerzenie praw spadkowych dzieci nieślubnych - tylko po ich matce. $Z$ analizy Autora książki wynika, że austriacka ustawa o wolności obrotu własnością ziemską z 1868 r. w okresie polskim 1918-1939 nie uległa zmianom co do treści, ale praktyka i jej wykładnia - tak. Pojawiły się tu tzw. włościańskie zwyczaje prawne, tzn. praktyka podziałów fizycznych gruntów włościańskich w Galicji, która prowadziła do rozdrobnienia chłopskich, często już za życia rodziców, a na pewno po ich śmierci - i z tym wszystkim musiały się mierzyć sądy lwowskie. W praktyce obrotu stosowano odmienne pojęcia na oznaczenie różnych instytucji prawnych niż terminologia kodeksowa, np. „grunt” - to parcela budowlana, a „pole” - to uprawy rolne. Jak jednak zauważył Autor książki, były przypadki z terenów zamożniejszych wsi, gdzie nie dzielono pola każdemu dziecku „po równo”, ale przekazywano jednemu z obowiązkiem spłat pozostałych.

5.2. Rozdział drugi książki zgodnie z jego tytułem „Podstawowe pojęcia” ma charakter wprowadzający do lektury. Cennym spostrzeżeniem Autora jest to, że ABGB nie posiadał definicji nieruchomości - co oznacza, że pozostawił jej rozumienie orzecznictwu sądowemu. Kodeks austriacki znał, za wzorcem rzymskim, podział rzeczy na ruchome i nieruchome. Częstą praktyką galicyjską było powoływanie znawców (biegłych) w oszacowaniu wartości nieruchomości do celów podatku spadkowego, ale i szerzej całego postępowania spadkowego. Pewne znaczenie miały również polskie przepisy prawne dotyczące reformy rolnej z lat 1919 i 1925. W poaustriackich zaś przepisach dotyczących obrotu nieruchomościami z 1905 r. obostrzeń w obrocie mortis causa nie było. Jeżeli chodzi o prawo zabudowy, to była to już sfera prawa rzeczowego, podobnie jak obrót nieruchomościami budynkowymi. W ocenie Autora pojęcie dziedzictwa (spuścizny) spadku w ABGB było zbyt wąskie. W ogóle prawo do dziedziczenia pojmowano jako jedno z praw podmiotowych (np. Stanisław Wróblewski) ${ }^{2}$, a postępowanie spadkowe zależało od tytułu dziedziczenia: kontrakt, testament i ustawa.

5.3. W rozdziale trzecim książki omówiono „Dziedziczenie testamentowe”. Otóż Autor uważa, że kodyfikatorzy austriaccy, kierując się zasadą indywidualizmu i priorytetem autonomii woli „spadkodawcy”, na pierwszym miejscu wśród sposobów dziedziczenia wysunęli dziedziczenie testamentowe przed ustawowym. Niemniej swoboda testowania ulegała licznym ograniczeniom, m.in. prawem dziedziców koniecznych, których ochrona praw spadkowych miała charakter względny - czyli mogli oni być np. wydziedziczeni. Prawo austriackie znało wielość form testamentów, mogły być pisemne (prywatne, publiczne i sądowe oraz notarialne) lub ustne. Gdy były wątpliwości co do zachowania właściwej formy przez testatora - to rozstrzygały sądy, na czele z wiedeńskim Sądem Najwyższym, ale później uprawnienia tegoż przejął nasz Sąd Najwyższy w Warszawie. Wiele kontrowersji budziły testamenty allograficzne, gdzie wymagano

${ }^{2}$ S. Wróblewski, Powszechny austriacki kodeks cywilny z uzupetniajacemi ustawami i rozporzadzeniami objaśniony orzeczeniami Sądu Najwyższego, cz. 1: (\$§ 1-937), Kraków 1914, s. 745 i nast. 
obecności trzech świadków, spisania testamentu przez jednego z nich i podpisania się spadkodawcy. Sprawy tego typu wzbudziły zainteresowanie doktryny i niemałą polemikę w niej (Maurycy Allerhand). Z ustaleń Autora książki wynika, że z kolei testamenty sądowe miały marginalną popularność, a notarialne nie były powszechnymi. Zresztą zbywanie nieruchomości według ABGB też nie musiało się odbywać w formie szczególnej, notarialnej - jak to mamy dzisiaj. Koredczuk ustalił, że najwięcej problemów natury prawnej wzbudzał testament ustny, i chodziło tu o różnego rodzaju wadliwości istniejące po stronie świadków rozrządzenia ostatniej woli. Testamenty uprzywilejowane (szczególne) sporządzano natomiast w czasie pomoru (głównie tyfusu), ale i tu było sporo problemów ze świadkami, i te sprawy były przedmiotem orzeczeń sądowych, z SN na czele. Jeżeli chodzi o testamenty wojskowe i żołnierskie, tu świadkowie też byli kontestowani, bo wielu z nich zmarło lub zginęło na wojnie. Instytucje prawa spadkowego, takie jak powiernictwo i podstawienie ( $\$ 72$ i nast.) także wzbudzały liczne kontrowersje prawne w doktrynie (Fryderyk Zoll ${ }^{3}$, Stanisław Wróblewski ${ }^{4}$ ) i orzecznictwie. Zdaniem Autora książki wyraźny wpływ na austriackie podstawienie miało prawo rzymskie oraz przepisy i nowoczesne poglądy doktryny prawa spadkowego w Niemczech o podstawieniu powierniczym i fideikomisach. Zdaniem Koredczuka osobny problem stwarzały instytucje opieki i kurateli oraz zarządu majątkiem małoletniego pupila przez jego opiekuna lub kuratora. Najczęstsze spory sądowe to próba oddzielenia przewodu sądowego spadkowego od przewodu opiekuńczego. Emocje prawne budziła też instytucja zapisu ( $§ 535,649)$, w tym jego szczególna postać - zapis naddziałowy (§ 648), a wśród podmiotów uprawnionych z legatu pieniężnego był swego czasu m.in. Uniwersytet Jagielloński (1938 r.). Kodycylem był tzw. testament negatywny - tzn. wykluczający krewnych spadkodawcy od dziedziczenia po nim. Instytucja ta była bardzo rozpowszechniona na wsi galicyjskiej, tak też sądy apelacji lwowskiej je traktowały, a nie kwalifikowały jako rozrządzenia testamentowego. Była to praktyka powszechna zdaniem Koredczuka. Często kodycyl sporządzano w formie ustnej, także na rzecz instytucji kościelnych i zakonnych. Liczne spory sądowe dotyczyły również nieważności rozrządzeń testamentowych z powodu wady formy testamentu lub były niewykonalne ze względu na jego treści. W swoim opracowaniu Autor pomija rozważania na temat wadliwości oświadczeń woli testatora jako niezdolnego do czynności prawnych (np. chorego psychicznie) - a szkoda, bo wyniki badań mogłyby przynieść jakieś nowe ustalenia naukowe.

5.4. W rozdziale czwartym Autor omówił „Dziedziczenie ustawowe”. ABGB - jako pierwszy z wielkich kodeksów epoki nowożytnej wprowadzał zasadę dziedziczenia ustawowego opartego na zasadzie parantel. Takie określenie uprawnionych krewnych spadkobiorcy do dziedziczenia po nim w praktyce stwarzało liczne problemy z ich ustaleniem, a także problemy z prawnym wykluczeniem małżonka żyjącego od dziedziczenia po swoim zmarlym małżonku. Dopiero nowela z 1914 r. zmieniała ten stan rzeczy, podobnie jak problem dziedziczenia ustawowego dzieci nieślubnych małżonka i sprawę

${ }^{3}$ F. Zoll, Prawo cywilne opracowane głównie na podstawie przepisów obowiazujacych w Małopolsce, t. 4: Prawo familijne i spadkowe, Poznań 1933, s. 199 i nast.

${ }^{4}$ S. Wróblewski, Podstawienie powiernicze, „Czasopismo Prawnicze i Ekonomiczne” 1903, t. 4, s. 531 i nast. 
tzw. majątków opuszczonych, niedziedzicznych. Te ostatnie miał dziedziczyć ex lege Skarb Państwa, ale wzbudzało to liczne spory w doktrynie, bo inni uważali, że powinna dziedziczyć gmina (Fryderyk Zoll) ${ }^{5}$. Jak już zaznaczyłem, krytyka naukowa i sądowa dotyczyła zbyt obszernego zdefiniowania kręgu spadkobierców ustawowych do trzech pradziadków i prababek po spadkodawcy. Często spadkodawca żyjących dalszych swoich krewnych już nie znał i być może nie wiedział o ich istnieniu, a mieliby po nim przejąć prawo własności jego majątku. Osobny problem wzbudzało dziedziczenie gospodarstw rolnych, bo zwyczaj spłat się nie przyjął. Kolejny problem to niegodność dziedziczenia przez cudzołożników spadkodawcy. Wreszcie wiele emocji natury praktycznej wzbudzała instytucja zabezpieczenia praw dziedziców koniecznych; spory w doktrynie były niemałe, bo jedni opowiadali się za zachowkiem (Stanisław Wróblewski), a inni za systemem rezerwy (Kazimierz Przybyłowski) ${ }^{7}$ - bo to byłoby zgodne z prawem natury. Najwięcej krytyki zebrały przepisy pomijające małżonka spadkodawcy w prawach do zachowku. Roszczenia z tytułu zachowków były przedmiotem licznych orzeczeń sądowych, były to spory o tzw. ukryte darowizny, które Autor książki określa jako ,jedną z plag ludu wiejskiego" - ale nie rozwija w szczegółach tematu. A szkoda.

5.5. W rozdziale piątym „Otwarcie i objęcie dziedzictwa” Autor książki skupił się na omówieniu chwili otwarcia spadku, bo według prawa austriackiego nie była nią chwila śmierci spadkodawcy, ale data wydania przez sąd spadkowy tzw. dekretu dziedzictwa. Na mocy tego aktu na spadkobiercę przechodził ogół praw i obowiązków zmarłego. Zatem problem prawny pojawiał się co do okresu pomiędzy tymi zdarzeniami prawnymi - czyli spadków wiszących (hereditas iacens). W tym czasie potencjalny dziedzic musiał się opowiedzieć, czy spadek przyjmuje, czy nie, a to rodziło liczne problemy prawne, w szczególności kiedy np. spadkobiorca był małoletni lub ułomny psychicznie. W dalszej kolejności omówiono kontrakt dziedziczenia (pkt 5.3) - jako jeden z trzech tytułów do dziedziczenia. Ten tytuł miał najsilniejszą moc, był nieodwołalny i wywoływał skutki po śmierci małżonka, czyli po ustaniu małżeństwa. Tym kontraktem nie można było rozporządzić całością majątku, ale $3 / 4$ części. Kontrakt ten powinien być zawarty $\mathrm{w}$ formie notarialnej, ale - jak ustalił Autor - ta forma spadkobrania miała marginalne zastosowanie w praktyce małopolskiej. Przyczyniła się do tego m.in. okoliczność, że tego kontraktu nie można było wpisać do ksiąg gruntowych. Stąd też w polskim projekcie prawa spadkowego tego tytułu spadkobrania miało już nie być. Innym sposobem zabezpieczenia praw małżonka było ustanowienie prawa dożywocia. Według Autora była to dość popularna instytucja $\mathrm{w}$ warunkach wiejskich i często ujawniana w księgach gruntowych. W praktyce umowa dożywocia wypełniała lukę prawną w postaci braku możliwości ustanowienia zachowku dla małżonka. Dalsze rozważania badacza koncentrują się na analizie charakteru prawnego wpisu do ksiąg gruntowych. Prawo austriackie uważało, że ma charakter stanowczy, czyli konstytutywny. W praktyce jednak wpisy

${ }^{5}$ F. Zoll, O podstawie rzymskiego prawa spadkowego beztestamentowego w porównaniu z dzisiejszemi prawodawstwami, „Rozprawy i sprawozdania z posiedzeń Wydziału Historyczno-Filozoficznego Akademii Umiejętności”, t. 24, Kraków 1889, s. 364.

6 S. Wróblewski, Zasady dziedziczenia ab intestato, „Czasopismo Prawnicze i Ekonomiczne” 1920, t. 18 , z. $1-4$, s. 163 i nast.

7 K. Przybyłowski, Rezerwa czy zachowek?, „Gazeta Sądowa Warszawska” 1939, t. 66, nr 21, s. 291. 
były lekceważone, a ponadto wiele ksiąg gruntowych zaginęło w czasie rosyjskiej okupacji terenów Małopolski wschodniej. Stąd też poważny problem stanowili faktyczni posiadacze nieruchomości rolnych, niewpisani do ksiąg gruntowych. Do czasów I wojny światowej w samej tylko apelacji lwowskiej było ok. 10 tys. procesów sądowych w tym zakresie. Niestety problem ten w okresie II RP tylko się pogłębiał. Wszystko to zdołał ustalić Autor monografii.

5.6. W zakończeniu Józef Koredczuk podkreśla, że poaustriackie ustawodawstwo spadkowe w okresie II RP odcisnęło znaczące piętno w świadomości prawnej ówczesnego społeczeństwa galicyjskiego. Niestety praktyka i zwyczaj prawny żyły własnym życiem. Reguły prawne i ich stosowanie w zakresie spadków dostrzegła zarówno doktryna, jak i praktyka, przede wszystkim notariusze (kongres w 1922 r.), jednakże nie doszło do uchwalenia polskiego rodzimego i jednolitego prawa spadkowego. Niemniej jednak Autor recenzowanej monografii udowodnił, że poaustriackie prawo spadkowe i jego praktyka stosowania wywarły znaczący wpływ na polskie ustawodawstwo spadkowe po II wojnie światowej, i nie chodzi tu tylko o instytucję zachowku.

\section{Inne uwagi}

Autor książki na początku swojej pracy na dwóch stronach zamieścił wykaz skrótów. Jego zawartość jest w pełni poprawna. Na przykład akronim austriackiego kodeksu cywilnego ABGB został rozwinięty i w pełnym niemieckojęzycznym brzmieniu i thumaczeniu na język polski umieszczony $\mathrm{w}$ wykazie wraz $\mathrm{z}$ datą dzienną ogłoszenia tego źródła prawa. Wraz z rozwinięciem skrótów/akronimów nazw sądów doprecyzowane są też informacje co do ich siedziby, np. wiedeński Najwyższy Trybunał czy też warszawski Najwyższy Trybunał Administracyjny.

Autor recenzowanej książki, badając materiał źródłowy wytworzony przez sądy apelacji lwowskiej i Sąd Najwyższy, natknął się na dane personalne podsądnych. Większość z tych danych obecnie uważa się za wrażliwe dane osobowe, które zwykle w odpowiedni sposób się utajnia, zastępując pełne dane personalne inicjałami pierwszych liter nazwiska i imienia. Autor recenzowanej książki owe wrażliwe dane personalne umiejętnie pomija lub utajnia.

Omawiana książka jest dopracowana doskonale pod względem językowym, stylistycznym i gramatycznym. Czytelnik ma wrażenie, jakby słyszał charakterystyczne w intonacji wywody samego jej Autora. Książkę czyta się z prawdziwą przyjemnością, zdania wynikają jedne z drugich, nie zmusza czytelnika do zadumy nad treścią, chyba że do refleksji na temat ówczesnego stanu prawa i praktyki jego stosowania. Niemniej zdarzają się tu drobne błędy edytorskie, czasami są podwójne spacje lub ich brak.

Indeks artykułowy liczy kilkadziesiąt jednostek normatywnych (głównie polskich źródeł prawa i jednego radzieckiego). Indeks osobowy liczy ponad 200 nazwisk, a indeks nazw geograficznych (miejscowych) liczy ok. 160 pozycji. 


\section{Zakończenie}

Kończąc swoje uwagi, chciałbym podkreślić, że książka prof. dra hab. Józefa Koredczuka zasługuje na bardzo pozytywną opinię. Inicjatywa badania instytucji „dziedziczenia nieruchomości" przez pryzmat praktyki orzecznictwa sądowego na południowo-wschodnich rubieżach II RP, gdzie obowiązywały przepisy recypowanego austriackiego kodeksu cywilnego (ABGB) z $1811 \mathrm{r}$. jest niezwykle pożądana. W tej mierze wiele miała do powiedzenia także utrwalona specyficzna praktyka prawnicza i zwyczaj miejscowy oraz pewnego rodzaju przyzwyczajenia lokalne jego mieszkańców. Na dość wysokim poziomie stoi analiza instytucji i zjawiska, zaś opis wyników badań pozostawia miejscami niedosyt. Niemniej widać wyraźnie, że profesor posiada zaawansowany poziom warsztatu naukowego podparty doświadczeniem w zakresie kwerendy archiwalnej na źródłach praktyki sądowej i innych, budowania kwestionariusza pytań badawczych, treści i obszerności stawiania hipotez, operowania różnymi danymi statystycznymi i wyciągania trafnych, chociaż nie zawsze wnikliwych wniosków badawczych. Książka w pełni dowodzi, że jej Autor posiadł umiejętność samodzielnego prowadzenia różnorodnych badań naukowych na bardzo wysokim poziomie naukowym i operuje z dużą precyzją słowa pięknym, polskim językiem prawniczym. A jest to zaleta dzisiaj coraz rzadsza.

W moim odczucie są tu treści, z którymi można się nie zgadzać lub polemizować, ale są one drugorzędne w stosunku do zagadnienia głównego. Należy także docenić że jest to książka historycznoprawna, napisana na trudny temat, jakim jest niewątpliwie dziedziczenie nieruchomości. Niemniej jest to praca okraszona różnymi wątkami o charakterze zwyczajowym z akt sądowych, co znacząco uwiarygadnia proces badawczy Autora.

Recenzowana książka jest pionierska w polskiej literaturze historycznoprawnej w zakresie badań nad poaustriackim prawem spadkowym z ABGB recypowanym na ziemiach polskich w okresie II RP. Wyniki badań w niej zawartych są w wielu miejscach nowatorskie w stosunku do dotychczasowego stanu wiedzy w polskiej literaturze przedmiotu i mają szansę być cytowane przez kolejne lata. Opracowanie powinno zainteresować nie tylko historyków prawa, ale także naukowców innych specjalności, np. historyków „bezprzymiotnikowych”, badaczy historii kultury materialnej i zwyczajów ludności miejskiej i wiejskiej, kultury społecznej i obyczajowości, migracji ludności, praw kobiet czy osób małoletnich bądź niepełnosprawnych w zakresie ich praw spadkowych lub inne osoby, którym brakuje informacji o obrocie nieruchomościami w okresie II Rzeczypospolitej.

\section{Bibliografia}

Koredczuk J., Dziedziczenie nieruchomości w świetle orzecznictwa sądów apelacji lwowskiej w okresie międzywojennym, Wrocław 2019.

Przybyłowski K., Rezerwa czy zachowek?, „Gazeta Sądowa Warszawska” 1939, R. 66, nr 21.

Wróblewski S., Podstawienie powiernicze, „Czasopismo Prawnicze i Ekonomiczne” 1903, t. 4.

Wróblewski S., Powszechny austriacki kodeks cywilny z uzupetniajacemi ustawami i rozporza- 
dzeniami objaśniony orzeczeniami Sądu Najwyższego, cz. 1: (\$\$ 1-937), Kraków 1914.

Wróblewski S., Zasady dziedziczenia ab intestato, „Czasopismo Prawnicze i Ekonomiczne” 1920, t. 18, z. 1-4.

Zoll F., O podstawie rzymskiego prawa spadkowego beztestamentowego w porównaniu z dzisiejszemi prawodawstwami, „Rozprawy i sprawozdania z posiedzeń Wydziału Historyczno-Filozoficznego Akademii Umiejętności”, t. 24, Kraków 1889.

Zoll F., Prawo cywilne opracowane głównie na podstawie przepisów obowiąujących w Małopolsce, t. 4: Prawo familijne i spadkowe, Poznań 1933. 